\title{
ПРИНЦИПИ СИНТЕЗУ АВТОМАТИЧНИХ СИСТЕМ КЕРУВАННЯ ПРОМИСЛОВИМИ КОНДИЦІОНЕРАМИ
} Голінко I.M. ${ }^{1}$

${ }^{1}$ Національний технічний університет України “КПІ”, Київ

E-mail: igor.golinko@conislab.net

Copyright (C) 2014 by author and the journal "Automation technological and business - processes". This work is licensed under the Creative Commons Attribution International License (CC BY). http://creativecommons.org/licenses/by/4.0/

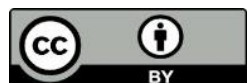

ONAFT

Open Access

\begin{abstract}
Анотація
Розглянуто основні принципи синтезу багатовимірних систем автоматичного керування для промислових комплексів штучного мікроклімату. Отримано комплексну динамічну модель промислового кондиціонера із паровим зволожувачем у просторі стану. Запропоновано метод контролю мікроклімату повітря за непрямим показником вологовмісту повітряної суміші, який розраховується програмно за виміряними значеннями температури та відносної вологості. Для промислового кондиціонера запропоновано процедуру синтезу багатовимірного лінійно-квадратичного цифрового регулятора із інтегральною складовою. Процедура синтезу багатовимірного регулятора відрізнясться від існуючих наявністю логіки вибору обладнання кондиціонера, де параметри регулятора адаптуються до властивостей кліматичного обладнання. Наведено приклад синтезу оптимального багатовимірного регулятора для кондиціонера CV-P 2L N-63B/F-N, синтезована матриця зворотного зв'язку, яка за параметрами стану об'скта визначає траєкторію вектора оптимального керування. Розглянуті принципи, математичні моделі, процедури та алгоритми рекомендується використовувати спеціалістам із автоматизації для синтезу та аналізу систем керування промисловими кондиціонерами.
\end{abstract}

\section{Abstract}

The base principle of multidimensional automatic control systems synthesis for artificial microclimate industrial systems is examined. The complex dynamic model of the industrial air conditioner with the steam humidifier in state space is gained. The method for an air microclimate monitoring by an indirect parameter of moisture content in air mix, which calculation is based on the measured values of temperature and a relative humidity, is offered. Synthesis procedure of a multidimensional linearly-quadric digital control with integral component for the industrial air conditioner is offered. Synthesis procedure of a multidimensional control differs from existing by presence of an air conditioner equipment sampling logic where control parameters adapt for the climatic equipment. The synthesis example of an optimal multidimensional control for air conditioner CV-P $2 \mathrm{~L}$ N-63B/F-N is resulted, the matrix of feedback is synthesized, which determines the vector of optimal control trajectory based on plant state. The principles, mathematical models, procedures and algorithms recommended to use by the automation specialists for synthesis and analysis of industrial conditioners control systems.

\section{Ключові слова}

Промисловий кондиціонер, динамічна модель, простір стану, автоматична система керування, оптимізація, лінійно-квадратичний цифровий регулятор. 
Вступ

Сучасні технології диктують високі вимоги до мікроклімату виробництва, від якого в значній мірі залежить якість продукції, зменшення іiі собівартості, а також впливає на ефективність роботи працівників. Спектр використання промислових комплексів штучного мікроклімату (ПКШМ) дуже широкий. Промислові кондиціонери є реальним важелем прибутку для технологій: легкої, харчової, аграрної, фармацевтичної, поліграфічної, машинобудівної, радіоелектронної та ряду інших галузей.

3 моменту винаходу кондиціонера Уіллісом Керрієром технологія кондиціювання повітря постійно вдосконалюється, зменшуючи їі питоме енергоспоживання. Сьогодні ПКШМ налічують більше 10-ка технологічних схем кондиціювання повітря [1,2]. Тому, ПКШМ можна виділити в окремий клас технологічних об'єктів, де для регулювання температури на вологості на виході кондиціонера (або у приміщенні) використовується від трьох одиниць кліматичного обладнання, причому кожний апарат може приймати участь у регулюванні.

Досягнення високих показників ефективності ПКШМ можливе тільки за умови коректного керування обладнанням кондиціонера, що передбачає аналіз структури автоматичної системи керування (АСК) та розробки відповідних алгоритмів керування. Промисловий кондиціонер представляє собою специфічний технологічний процес. Діапазон зміни вхідних та вихідних величин (навантажень, параметрів навколишнього середовища, відхилень регульованих параметрів та інше) дуже широкий. В залежності від використаного обладнання, промисловий кондиціонер як об'єкт керування (OK) є складним та нелінійним [2]. Ряд керуючих впливів обмежений та носить позиційний характер, що негативно впливає на якість керування, а деякі елементи системи залишаються некерованими. 3 цих причин застосовують нетрадиційні рішення з автоматизації.

Аналіз літературних джерел із автоматизації ПКШМ виділяє якісне і кількісне керування процесом кондиціювання повітря, де використовується метод “точки роси”. Існуючі рішення із автоматизації ПКШМ обмежуються на рівні побудови функціональних схем та вибору типу регулятора [3]. При цьому для синтезу АСК кондиціонера розглядається динаміка тільки теплообмінних процесів кліматичного обладнання [3, 4], так як температура “точки роси” є непрямим показником вологості. Керування за методом “точки роси” характеризується значною перевитратою холодо- та теплоносія, що пояснюється охолодженням повітря до температури “точки роси” і повторним нагріванням на калорифері другого підігріву.

За останні десятиліття у промислових кондиціонерах почали використовуватися парогенератори, ультразвукові, плівкові, капілярно-пористі та інші типи зволожувачів [5]. Така технологія зволоження дозволяє уникнути додаткового охолодження повітря із повторним нагріванням. При цьому для керування кондиціонером використовується метод “оптимального режиму”. В таких системах керування необхідно враховувати взаємний вплив контурів регулювання температури та вологості. Наявні на сьогодні підходи до розв’язання задач автоматизації ПКШМ за методом “оптимального режиму” не відповідають сучасним вимогам [2]. Літературний аналіз підтверджує, що питання синтезу взаємопов’язаних контурів керування для ПКШМ розглянуто недостатньо [2, 3].

Виходячи із викладеного, синтез АСК промислового кондиціонера пропонується проводити в рамках єдиного комп'ютерно-інтегрованого комплексу із врахуванням технологічних зв'язків між кліматичним обладнанням, що $є$ першим принципом синтезу сучасної АСК ПКШМ [6].

\section{Математичні моделі обладнання ПКШМ}

Технологія кондиціювання визначає склад кліматичного обладнання. Серед основного обладнання промислового кондиціонера слід виділити: теплообмінні апарати для нагріву, охолодження та конденсації вологи повітря; зволожувачі, основною задачею яких є зволоження повітря. Також, в промислових кондиціонерах використовується обладнання для утилізації тепла витяжного повітря, серед якого камери змішування повітря та теплообмінні рекуператори різного принципу дії. Для синтезу АСК ПКШМ найчастіше досліджується динаміка теплообмінних процесів обладнання кондиціонера [2,3].

Останнім часом з'являються публікації де розглядається динаміка тепломасообмінних процесів кліматичного обладнання [7, 8]. У роботах [9-11] динамічні моделі тепломасообміну обладнання кондиціонера представлено матричною передатною функцією та рівноцінною залежністю у просторі стану. Тут типовий динамічний елемент кліматичного обладнання розглядається як багатовимірний ОК із п’ятьма входами та двома виходами входами. У [12] запропоновано методику розробки комплексної моделі промислового кондиціонера, яка дозволяє у просторі стану із наявних математичних моделей кліматичного обладнання отримати комплексну динамічну модель промислового кондиціонера з врахуванням взаємозв'язків між обладнанням.

\section{Постановка задачі}

Метою публікації є формулювання основних принципів розробки сучасної системи керування промисловим кондиціонером на прикладі синтезу АСК промислового кондиціонера із парозволожувачем. 
Аналіз аналітичних моделей кліматичного обладнання дозволяє зробити висновок, що типовий динамічний елемент обладнання кондиціонера можна розглядати як багатовимірний ОК. Враховуючи наявність методики розробки комплексної моделі промислового кондиціонера у просторі стану, 3'являється можливість синтезу багатовимірного регулятора у просторі стану, що є предметом дослідження даної статті.

Комплексна динамічна модель кондиціонера із паровим зволожувачем

Представлення динамічної моделі ОК в просторі стану має ряд переваг порівняно із записом у вигляді передатних функцій. Наприклад, дозволяє описати довільні внутрішні структури, некеровані та неспостережені параметри ОК за допомогою мінімального числа змінних. Якщо математичний опис ОК складено із врахуванням присутності спільних змінних стану, то така модель містить мінімальне число змінних стану, а форма опису відповідає мінімальній реалізації математичної моделі ОК. Додатковим аргументом на користь векторних моделей $є$ велика кількість математичних пакетів для комп'ютерного аналізу технічних систем у просторі стану, які дозволяють із незначними часовими витратами проводити складні математичні дослідження.

Використовуючи методику описану у [12] та враховуючи наявність динамічних моделей кліматичного обладнання $[9,10]$, отримано комплексну модель у просторі стану для стельового кондиціонера CV-P 2L N-63B/F-N iз паровим зволожувачем, який виготовляє фірма VTS CLIMA [13]:

$$
\begin{aligned}
& \left\{\begin{array}{l}
\mathbf{X}^{\prime}=\mathbf{A X}+\mathbf{B U}+\mathbf{D F} \\
\mathbf{Y}=\mathbf{C X}
\end{array}\right. \\
& \text { де } \mathbf{A}=\left[\begin{array}{llll}
\mathbf{A}^{\mathrm{K} 1} & \mathbf{0} & \mathbf{0} & \mathbf{0} \\
\mathbf{C}_{1} & \mathbf{A}^{\mathrm{O}} & \mathbf{0} & \mathbf{0} \\
\mathbf{0} & \mathbf{C}_{2} & \mathbf{A}^{\mathrm{K} 2} & \mathbf{0} \\
\mathbf{0} & \mathbf{0} & \mathbf{C}_{3} & \mathbf{A}^{\Pi 3}
\end{array}\right], \mathbf{X}=\left[\begin{array}{l}
\mathbf{X}^{\mathrm{K} 1} \\
\mathbf{X}^{\mathrm{O}} \\
\mathbf{X}^{\mathrm{K} 2} \\
\mathbf{X}^{\Pi 3}
\end{array}\right] ; \mathbf{B}=\left[\begin{array}{llll}
\mathbf{B}_{1}^{\mathrm{K} 1} & \mathbf{0} & \mathbf{0} & \mathbf{0} \\
\mathbf{0} & \mathbf{B}_{1}^{\mathrm{O}} & \mathbf{0} & \mathbf{0} \\
\mathbf{0} & \mathbf{0} & \mathbf{B}_{1}^{\mathrm{K} 2} & \mathbf{0} \\
\mathbf{0} & \mathbf{0} & \mathbf{0} & \mathbf{B}_{1}^{\Pi 3}
\end{array}\right], \mathbf{U}=\left[\begin{array}{c}
\mathbf{U}_{1}^{\mathrm{K} 1} \\
\mathbf{U}_{1}^{\mathrm{O}} \\
\mathbf{U}_{1}^{\mathrm{K} 2} \\
\mathbf{U}_{1}^{\Pi 3}
\end{array}\right] ; \mathbf{D}=\left[\begin{array}{c}
\mathbf{B}_{2}^{\mathrm{K} 1} \\
\mathbf{0} \\
\mathbf{0} \\
\mathbf{0}
\end{array}\right], \mathbf{F}=\mathbf{F}_{2}^{\mathrm{K} 1} ;
\end{aligned}
$$

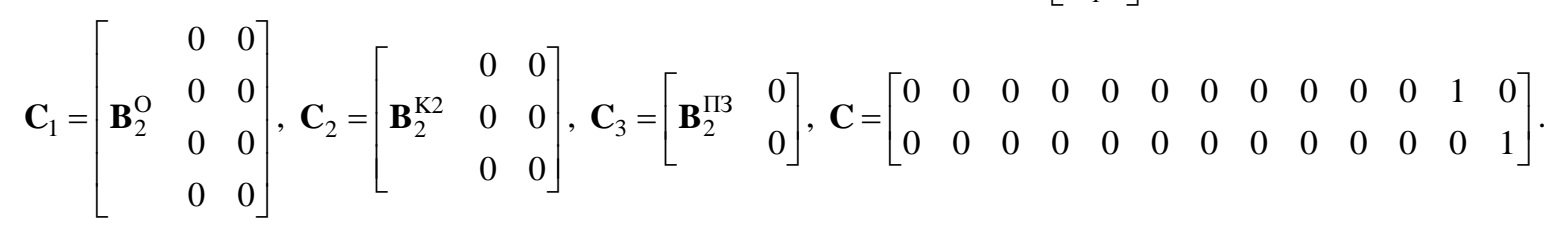

Комплексну динамічну модель ПКШМ розроблено із врахуванням спільних змінних стану, на що вказує наявність недіагональних елементів матриці стану А. Комплексна модель промислового кондиціонера (1) містить динамічні моделі кліматичного обладнання: водяних калорифера К1 та охолоджувача О четвертого порядку; електричного калорифера К2 третього порядку; парового зволожувача ПЗ другого поряду. При розробці комплексної моделі враховано порядок динамічних моделей кліматичного обладнання, що відображено у матрицях $\mathbf{C}_{1}-\mathbf{C}_{3}$. Модель (1) має тринадцятий порядок, розмірність матриць: А $-[13 \times 13], \mathbf{B}-[4 \times 13]$. Зовнішні детерміновані збурення представлено вектором $\mathbf{F}$, змінними якого є температура та вологість навколишнього повітря.

Для VAV (Variable Air Volume) систем штучного мікроклімату можна враховувати витрату повітря, у цього випадку наповнення матриць $\mathbf{D}$ та $\mathbf{F}$ дещо зміниться. Якщо розглядається прецизійна система кондиціювання повітря для промислового приміщення, необхідно отримати динамічну модель приміщення у просторі стану та врахувати ії у моделі ПКШМ (1).

Процедура синтезу багатовимірного цифрового регулятора із інтегральною складовою

Для оптимізації багатовимірної системи керування із моделлю ОК (1) пропонується використати дискретний аналог квадратичного критерію якості [14]:

$$
I=\mathbf{X}_{N}^{\mathrm{T}} \mathbf{S} \mathbf{X}_{N}+\sum_{s=0}^{N-1}\left[\mathbf{X}_{s}^{\mathrm{T}} \mathbf{Q} \mathbf{X}_{s}+\mathbf{U}_{s}^{\mathrm{T}} \mathbf{R} \mathbf{U}_{s}\right]
$$

де, $\mathbf{S}, \mathbf{Q}$ - вагові додатні напіввизначені матриці; $\mathbf{R}$ - вагова симетрична додатна матриця; $\mathbf{X}_{s}, \mathbf{U}_{s}-$ відповідно вектор стану та вектор керування об'єкта на $s$-му кроці дискретизації із періодом $T_{K V}, N$ - кількість кроків спостереження.

У теорії оптимізації динамічних систем розглянуто багато прикладів синтезу оптимальних регуляторів, які мають розв'язок у вигляді пропорційних матриць зворотного зв'язку $[14,15]$ та за своєю фізичною суттю представляють ПДрегулятор високого порядку Як відомо, із класичної теорії керування, пропорційні регулятори не забезпечують точного відслідковування завдання та не повністю компенсують збурення у системі керування. 3 цих причин необхідно переформулювати постановку задачі синтезу регулятора стану таким чином, щоб у керуванні з'явилася інтегральна складова, яка компенсує статичний небаланс регулювання. Це можна зробити декількома способами. 
Один з них [15] - розширення простору стану шляхом доповнення $n$-мірного вектору стану $\mathbf{X} p$-мірним вектором за яким необхідно мати інтегруючий вплив на ОК

$$
\mathbf{Z}^{\prime}=\mathbf{C} \mathbf{X}
$$

В результаті зростає розмірність вектору стану на $p$ (на кількість нових змінних), простір стану опишеться $(p+m)-$ мірним вектором, де розширена модель ОК в просторі стану прийме вигляд

$$
\left[\begin{array}{l}
\mathbf{X}^{\prime} \\
\mathbf{Z}^{\prime}
\end{array}\right]=\left[\begin{array}{ll}
\mathbf{A} & \mathbf{0} \\
\mathbf{C} & \mathbf{0}
\end{array}\right]\left[\begin{array}{l}
\mathbf{X} \\
\mathbf{Z}
\end{array}\right]+\left[\begin{array}{c}
\mathbf{B} \\
\mathbf{0}
\end{array}\right] \mathbf{U}
$$

Детермінована складова збурення DF у моделі (5) не розглядається, так як роль детермінованого збурення у класичній постановці синтезу багатовимірного регулятора прийнято моделювати ступінчатим відхиленням вектора змінних стану від усталеного режиму у нульовий момент часу.

Для розширеного простору стану у неперервній формі лінійно-квадратичний регулятор формує ПІ-закон керування $\mathbf{U}=-\mathbf{K}\left[\begin{array}{l}\mathbf{X} \\ \mathbf{Z}\end{array}\right]=-\mathbf{K}_{\mathrm{P}} \mathbf{X}-\mathbf{K}_{\mathrm{I}} \mathbf{Z}=-\mathbf{K}_{\mathrm{P}} \mathbf{X}-\mathbf{K}_{\mathrm{I}} \mathbf{C} \int \mathbf{X} d t$, тут $\mathbf{K}-$ матриця багатовимірного регулятору, що складається із пропорційної $\mathbf{K}_{\mathrm{P}}$ та інтегральної $\mathbf{K}_{\mathrm{I}}$ частин. Необхідною умовою існування такого регулятора $є$ виконання нерівності $p<m$, тобто число змінних стану для яких вводиться інтегральний вплив не може бути більшим числа змінних керування.

Задачу синтезу оптимального лінійно-квадратичного цифрового регулятора (ЛКЦР) для ПКШМ можна сформулювати наступним чином. Нехай, відповідно до технології кондиціювання, модель ОК задано моделлю (1). Потрібно синтезувати матрицю зворотного зв'язку $\mathbf{K}_{\mathbf{d}}$ ЛКЦР, яка за параметрами стану ОК визначить траєкторію вектора оптимального впливу $\mathbf{U}_{s}^{o}$ для $s=1,2, \ldots N-1$, що мінімізує критерій якості (3).

Перед усім, неперервну модель ОК (1) необхідно розширити змінними (4), за якими необхідно мати інтегральну складову у законі керування та отримати розширену модель ОК у просторі стану (5). Далі, розширену неперервну модель ОК потрібно привести до дискретного вигляду:

$$
\left\{\begin{array}{l}
\mathbf{X}_{s+1}=\mathbf{A}_{\mathbf{d}} \mathbf{X}_{s}+\mathbf{B}_{\mathbf{d}} \mathbf{U}_{s} \\
\mathbf{Y}_{s}=\mathbf{C}_{\mathbf{d}} \mathbf{X}_{s}
\end{array}\right.
$$

де $\mathbf{A}_{\mathbf{d}}=e^{\mathbf{A} T_{K V}}, \mathbf{B}_{\mathbf{d}}=\int_{0}^{T_{K V}} e^{\mathbf{A}\left(T_{K V}-\tau\right)} \mathbf{B} d \tau$.

В загальному випадку оптимальний ЛКЦР представляється залежністю [14]

$$
\mathbf{U}_{s}=-\mathbf{K}_{\mathbf{d}} \mathbf{X}_{s} .
$$

Регулятор формує зворотний зв'язок за станом параметрів ОК, використовуючи матрицю коефіцієнтів передачі $\mathbf{K}_{\mathbf{d}}$. Матриця зворотного зв'язку визначається залежністю

$$
\mathbf{K}_{\mathbf{d}}=\left(\mathbf{R}+\mathbf{B}_{\mathbf{d}}^{\mathrm{T}} \mathbf{P} \mathbf{B}_{\mathbf{d}}\right)^{-1} \mathbf{B}_{\mathbf{d}}^{\mathrm{T}} \mathbf{P} \mathbf{A}_{\mathbf{d}}
$$

Параметри такого регулятора визначаються в результаті рішення рівняння Ріккаті. При $\mathbf{P}=\mathbf{P}_{0}$ проводиться розв'язок стаціонарного матричного рівняння Ріккаті

$$
\mathbf{P}=\mathbf{Q}+\mathbf{A}_{\mathbf{d}}^{\mathrm{T}} \mathbf{P}\left[\mathbf{I}-\mathbf{B}_{\mathbf{d}}\left(\mathbf{R}+\mathbf{B}_{\mathbf{d}}^{\mathrm{T}} \mathbf{P} \mathbf{B}_{\mathbf{d}}\right)^{-1} \mathbf{B}_{\mathbf{d}}^{\mathrm{T}} \mathbf{P}\right] \mathbf{A}_{\mathbf{d}} .
$$

Процедура синтезу ЛКЦР зводиться до наступної послідовності дій:

1) задаються параметри критерію (3) відповідно до технологічних вимог виробництва;

2) формується розширена неперервна модель ОК (5);

3) на основі (5) визначається дискретна модель ОК (6);

4) шукається розв'язок рівняння Рікатті (9);

5) за залежністю (8) визначаються параметри ЛКЦР.

В залежності від технології промислового кондиціювання повітря, для стабілізації температури та вологості на виході промислового кондиціонера (або у приміщенні) використовується від 3-ох до 5-ти одиниць кліматичного обладнання. При цьому, у керуванні приймає участь не більше 2-х апаратів, оскільки регулюється два параметри температура та вологість повітря. Із теорії керування відомо, що кількість параметрів регулювання повинна відповідати кількості керуючих впливів на ОК. У даному випадку кількість регулюючих каналів більша за кількість параметрів регулювання. 3 цих причин виникає задача коректного логічного вибору обладнання для здійснення керуючих впливів. Дана особливість накладає обмеження на використання класичної процедури синтезу 
оптимального ЛКЦР. Враховуючи наявність логічних перемикань між обладнанням кондиціонера задачу синтезу необхідно поділити на окремі підзадачі, що дозволить врахувати наявність логічного керування. Синтез ЛКЦР для промислових кондиціонерів із елементами логічного керування розглянуто далі на прикладі стельового кондиціонера CV-P 2L N-63B/F-N із паровим зволожувачем.

\section{Синтез оптимального ЛКЦР для кондиціонера із паровим зволожувачем}

Промисловий кондиціонер із паровим зволожувачем орієнтований на застосування алгоритму керування за методом “оптимального режиму” [16]. Для даного методу керування АСК стабілізує температуру та вологість навиході промислового кондиціонера (або у приміщенні), шляхом регулюючих впливів на кліматичне обладнання, при цьому безпосередню участь у регулюванні приймає тільки два технологічні апарати із чотирьох можливих. Логічний вибір кліматичного обладнання для обробки навколишнього повітря залежить від пори року та характеризується температурою та вологістю повітря.

Сьогодні АСК регулюють температуру та відносну вологість повітря на виході ПКШМ або у приміщенні. Для модифікованого методу “оптимального режиму” в якості параметрів регулювання АСК ПКШМ запропоновано використовувати температуру та вологовміст повітря, що є другим характерним принципом синтезу сучасної АСК ПКШМ. Значення вологовмісту залишається постійним при нагріванні повітря на калориферах, в той час як відносна вологість зменшується (зміна температури на $1{ }^{\circ} \mathrm{C}$ приводить до зміни відносної вологості близько 3 \%). При охолоджені повітря (до моменту конденсації вологи) вологовміст також залишається постійним. Такий підхід дозволяє розмежувати вплив між контурами регулювання температури та вологості для єдиного матеріального потоку повітряної суміші.

На основі відомих залежностей для відносної вологості, вологовмісту повітря та використовуючи апроксимуючу залежність Фільнеєма між тиском та температурою насиченої пари [17] запропоновано математичну модель непрямого контролю вологовмісту

$$
d=\frac{83045.9 \cdot \varphi \cdot 10^{\frac{156+8.12 \theta}{236+\theta}}}{P_{\sigma}-133.3 \cdot \varphi \cdot 10^{\frac{156+8.12 \theta}{236+\theta}}},
$$

яка за виміряною температурою $\theta$, відносною вологістю $\varphi$ та барометричним тиском $P_{\sigma}$ повітряної суміші визначає вологовміст повітря. Залежність (10) справедлива для робочого діапазону промислових кондиціонерів та легко реалізується на комп'ютерних засобах автоматизації.

Логічний вибір обладнанням кондиціонера для обробки повітря проводиться із використанням $h-d$ діаграми [1, 2]. Розглянемо процес кондиціювання повітря за методом “оптимального режиму” в координатах математичної моделі (1). На рис. 1 представлено $h-d$ діаграму процесу кондиціювання повітря. Для моделі (1) температура повітря на вході кондиціонера може змінюватися в діапазоні $\theta_{A 0}^{\min } \ldots \theta_{A 0}^{\max }$, а вологовміст $-d_{0}^{\min } \ldots d_{0}^{\max }$. На діаграмі представлено 7 областей. Область V задовольняє необхідні параметри мікроклімату на виході ПКШМ в діапазоні допустимої зони розбалансу для температури $-x_{12}^{\min } \ldots x_{12}^{\max }$ та вологовмісту $-x_{13}^{\min } \ldots x_{13}^{\max }$ повітря. Область III для кліматичних умов України практичного інтересу не представляє і розглядаються формально.

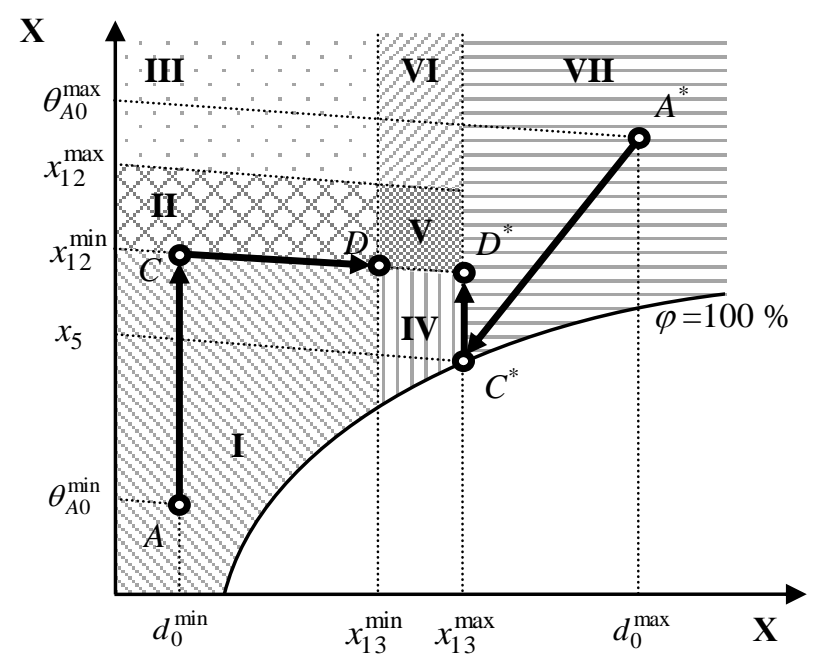

Рис. $1-H-d$ діаграма в координатах математичної моделі (1) 
Аналіз областей $h-d$ діаграми дозволяє рекомендувати алгоритм логічного керування обладнанням кондиціонера за модифікованим методом “оптимального режиму”.

Область І. АСК стабілізує:

- температуру повітря на виході ПКШМ впливом на калорифер К1 (пряма $A C$, рис. 1);

- вологовміст повітря на виході ПКШМ впливом на паровий зволожувач ПЗ кондиціонера (пряма $C D$, рис. 1$)$.

Область II. АСК стабілізує:

• вологовміст повітря на виході ПКШМ впливом на паровий зволожувач ПЗ кондиціонера, інше кліматичне обладнання участі у регулюванні не приймає, температура повітря знаходиться у допустимих межах.

Область III. АСК стабілізує:

- температуру повітря на виході ПКШМ впливом на охолоджувач O;

• вологовміст повітря на виході ПКШМ впливом на паровий зволожувач ПЗ кондиціонера.

Область IV. АСК стабілізує:

- температуру повітря на виході ПКШМ впливом на калорифер К2, інше кліматичне обладнання участі у регулювання не приймає, вологовміст повітря знаходиться у допустимих межах.

Область V. Параметри мікроклімату знаходяться у допустимих межах, регулюючі клапани кліматичного обладнання у закритому положенні.

Область VI. АСК стабілізує:

- температуру повітря на виході ПКШМ впливом на охолоджувач O, інше кліматичне обладнання участі у регулювання не приймає, вологовміст повітря знаходиться у допустимих межах.

Область VII. АСК стабілізує:

- температуру повітря на виході ПКШМ впливом на калорифер К2;

- вологовміст повітря на виході ПКШМ впливом на охолоджувач О (пряма $A^{*} C^{*}$, рис. 1). При конденсації надмірної вологи, зменшується температура повітря за охолоджувачем до $x_{5}$, після чого необхідно додатково нагріти повітря на калорифері К2 (пряма $\left.C^{*} D^{*}\right)$.

Для синтезу оптимального ЛКЦР, що реалізує ПІ-закон регулювання розширимо математичну модель (1) параметрами стану за якими необхідно мати інтегральну складову у законі керування. У даному випадку стабілізується температура та вологовміст повітря на виході ПКШМ, вибір яких здійснюється матрицею С моделі (1). Враховуючи алгоритм логічного вибору обладнання кондиціонера, розширена неперервна модель ОК для промислового кондиціонера із паровим зволожувачем прийме вигляд:

$$
\begin{gathered}
\left\{\begin{array}{l}
{\left[\begin{array}{l}
\mathbf{X}^{\prime} \\
\mathbf{Z}^{\prime}
\end{array}\right]=\left[\begin{array}{ll}
\mathbf{A} & \mathbf{0} \\
\mathbf{C} & \mathbf{0}
\end{array}\right]\left[\begin{array}{l}
\mathbf{X} \\
\mathbf{Z}
\end{array}\right]+\left[\begin{array}{c}
\mathbf{B}_{\mathrm{I} \ldots \mathrm{VII}} \\
\mathbf{0}
\end{array}\right] \mathbf{U} ;} \\
\mathbf{Y}=\mathbf{C X} \mathbf{X}
\end{array}\right. \\
\text { де } \mathbf{B}_{\mathrm{I}}=\left[\begin{array}{llll}
\mathbf{B}_{1}^{\mathrm{K} 1} & \mathbf{0} & \mathbf{0} & \mathbf{0} \\
\mathbf{0} & \mathbf{0} & \mathbf{0} & \mathbf{0} \\
\mathbf{0} & \mathbf{0} & \mathbf{0} & \mathbf{0} \\
\mathbf{0} & \mathbf{0} & \mathbf{0} & \mathbf{B}_{1}^{\Pi 3}
\end{array}\right] ; \mathbf{B}_{\mathrm{II}}=\left[\begin{array}{llll}
\mathbf{0} & \mathbf{0} & \mathbf{0} & \mathbf{0} \\
\mathbf{0} & \mathbf{0} & \mathbf{0} & \mathbf{0} \\
\mathbf{0} & \mathbf{0} & \mathbf{0} & \mathbf{0} \\
\mathbf{0} & \mathbf{0} & \mathbf{0} & \mathbf{B}_{1}^{\Pi 3}
\end{array}\right] ; \mathbf{B}_{\mathrm{III}}=\left[\begin{array}{llll}
\mathbf{0} & \mathbf{0} & \mathbf{0} & \mathbf{0} \\
\mathbf{0} & \mathbf{B}_{1}^{\mathrm{O}} & \mathbf{0} & \mathbf{0} \\
\mathbf{0} & \mathbf{0} & \mathbf{0} & \mathbf{0} \\
\mathbf{0} & \mathbf{0} & \mathbf{0} & \mathbf{B}_{1}^{\Pi 3}
\end{array}\right] ; \mathbf{B}_{\mathrm{IV}}=\left[\begin{array}{llll}
\mathbf{0} & \mathbf{0} & \mathbf{0} & \mathbf{0} \\
\mathbf{0} & \mathbf{0} & \mathbf{0} & \mathbf{0} \\
\mathbf{0} & \mathbf{0} & \mathbf{B}_{1}^{\mathrm{K} 2} & \mathbf{0} \\
\mathbf{0} & \mathbf{0} & \mathbf{0} & \mathbf{0}
\end{array}\right] ; \\
\mathbf{B}_{\mathrm{V}}=\left[\begin{array}{llll}
\mathbf{0} & \mathbf{0} & \mathbf{0} & \mathbf{0} \\
\mathbf{0} & \mathbf{0} & \mathbf{0} & \mathbf{0} \\
\mathbf{0} & \mathbf{0} & \mathbf{0} & \mathbf{0} \\
\mathbf{0} & \mathbf{0} & \mathbf{0} & \mathbf{0}
\end{array}\right] ; \mathbf{B}_{\mathrm{VI}}=\left[\begin{array}{llll}
\mathbf{0} & \mathbf{0} & \mathbf{0} & \mathbf{0} \\
\mathbf{0} & \mathbf{B}_{1}^{\mathrm{O}} & \mathbf{0} & \mathbf{0} \\
\mathbf{0} & \mathbf{0} & \mathbf{0} & \mathbf{0} \\
\mathbf{0} & \mathbf{0} & \mathbf{0} & \mathbf{0}
\end{array}\right] ; \mathbf{B}_{\mathrm{VII}}=\left[\begin{array}{llll}
\mathbf{0} & \mathbf{0} & \mathbf{0} & \mathbf{0} \\
\mathbf{0} & \mathbf{B}_{1}^{\mathrm{O}} & \mathbf{0} & \mathbf{0} \\
\mathbf{0} & \mathbf{0} & \mathbf{B}_{1}^{\mathrm{K} 2} & \mathbf{0} \\
\mathbf{0} & \mathbf{0} & \mathbf{0} & \mathbf{0}
\end{array}\right] .
\end{gathered}
$$

Наповнення матриці керування $\mathbf{B}_{\text {I...VII }}$ для областей $h-d$ діаграми індивідуальне, що дозволяє організувати логіку перемикання кліматичного обладнання в залежності від параметрів мікроклімату навколишнього середовища. Враховуючи індивідуальність наповнення матриці керування $\mathbf{B}_{\mathrm{I} . . \mathrm{VII}}$, за розглянутою вище процедурою синтезу ЛКЦР необхідно синтезувати матрицю зворотного зв’язку $\mathbf{K}_{\mathbf{d} \text { I...VII }}(8)$ для кожної області $h-d$ діаграми.

Для перемикання між матрицями зворотного зв'язку $\mathbf{K}_{\mathbf{d I - V I I}}$ у алгоритмі керування кондиціонером необхідно передбачити контроль параметрів мікроклімату навколишнього середовища. Вологовміст повітря пропонується визначати програмним способом за моделлю (10) та виміряними значеннями температури та відносної вологості 
повітря. Таким чином, маємо справу із адаптивною багатовимірною АСК ПКШМ, так як параметри матриці зворотного зв'язку $\mathbf{K}_{\mathbf{d}}$ ЛКЦР індивідуальні для семи областей $h-d$ діаграми.

Приклад синтезу ЛКЦР для кондиціонера CV-P 2L N-63B/F-N

За публікаціями $[9,10]$ отримано чисельні значення для матриць математичних моделей обладнання кондиціонера CV-P 2L N-63B/F-N у просторі стану. Нижче представлено чисельні значення матриць обладнання.

Водяний калорифер К1 першого підігріву CVP2-HW2:

$$
\mathbf{A}^{\mathrm{K} 1}=\left[\begin{array}{llll}
-8.7255 & 0 & 6.3366 & 0 \\
0 & -1 & 0 & 0 \\
0.9238 & 0 & -1.6648 & 0.741 \\
0 & 0 & 0.1397 & -0.298
\end{array}\right] ; \mathbf{B}_{1}^{\mathrm{K} 1}=\left[\begin{array}{c}
0 \\
0 \\
0 \\
0.1582
\end{array}\right] ; \mathbf{B}_{2}^{\mathrm{K} 1}=\left[\begin{array}{ll}
2.3889 & 0 \\
0 & 1 \\
0 & 0 \\
0 & 0
\end{array}\right] .
$$

Водяний охолоджувач CVP2-CW4:

$$
\mathbf{A}^{\mathrm{O}}=\left[\begin{array}{llll}
-7.1634 & -16.001 & 10.96 & 0 \\
0 & -7.0691 & 2.733 & 0 \\
0.348 & 0 & -0.8735 & 0.5254 \\
0 & 0 & 0.0991 & -0.1782
\end{array}\right] ; \mathbf{B}_{1}^{\mathrm{O}}=\left[\begin{array}{r}
0 \\
0 \\
0 \\
-2.2152
\end{array}\right] ; \mathbf{B}_{2}^{\mathrm{O}}=\left[\begin{array}{ll}
2.3889 & 5.336 \\
0 & 2.3575 \\
0 & 0 \\
0 & 0
\end{array}\right] .
$$

Електричний калорифер К2 другого підігріву НЕ36/2:

$$
\mathbf{A}^{\mathrm{K} 2}=\left[\begin{array}{lll}
-2.4958 & 0 & 0.1332 \\
0 & -1 & 0 \\
0.0887 & 0 & -0.0887
\end{array}\right] ; \mathbf{B}_{1}^{\mathrm{K} 2}=\left[\begin{array}{c}
0 \\
0 \\
0.0036
\end{array}\right] ; \mathbf{B}_{2}^{\mathrm{K} 2}=\left[\begin{array}{ll}
2.3626 & 0 \\
0 & 1 \\
0 & 0
\end{array}\right] .
$$

Паровий зволожувач humiSteam UE005:

$$
\mathbf{A}^{\Pi 3}=\left[\begin{array}{ll}
-1.3471 & -3.009 \\
0 & -1.3471
\end{array}\right] ; \mathbf{B}_{1}^{\Pi 3}=\left[\begin{array}{l}
3.253 \\
1.456
\end{array}\right] ; \mathbf{B}_{2}^{\Pi 3}=\left[\begin{array}{ll}
1.3471 & 3.009 \\
0 & 1.3471
\end{array}\right] .
$$

Наведені чисельні значення використано у (2) для розрахунку матриць комплексної моделі кондиціонера (1). Далі, комплексну модель (1) приведено до розширеного вигляду (5). Використовуючи функції MatLAB ss(a,b,c,d) та c2d(sys,Ts) за розширеною моделлю (5) розраховано параметри матриць $\mathbf{A}_{\mathbf{d}}$, $\mathbf{B}_{\mathbf{d}}$ дискретної моделі (6) із періодом дискретизації $T_{K V}=1$. Числові параметри моделі (6) розраховано для I області $h-d$ діаграми (див. рис. 1, зимовий режим роботи кондиціонера). Матриця керування $\mathbf{B}_{\mathbf{d}}$ розглядається як $\mathbf{B}_{\mathrm{I}}$, у керуванні приймає участь тільки калорифер К1 та парозволожувач ПЗ. Використовуючи функції MatLAB $\operatorname{rank}(\operatorname{ctrb}(\mathrm{Ad}, \mathrm{Bd})) \operatorname{Ta} \operatorname{rank}(\mathrm{obsv}(\mathrm{Ad}, \mathrm{Cd}))$, визначено ранги матриць керованості та спостережуваності для розширеної цифрової моделі ОК (6). Результати розрахунків підтвердили, що система (6) керована та спостережна.

Параметри критерію якості (3) задано матрицями $\mathbf{S}=\mathbf{0} ; \mathbf{R}=\mathbf{0} \mathbf{Q}=\mathbf{I}$, де $\mathbf{I}$ - одинична діагональна матриця. Використовуючи функцію MatLAB dlqr(Ad,Bd,Q,...), для дискретної моделі (6) визначено матрицю зворотного зв’язку $\mathbf{K}_{\mathbf{d} \text { I }}$ (8) на основі розв'язку рівняня Рікатті $\mathbf{P}(9)$. Чисельні значення матриць $\mathbf{A}_{\mathbf{d}}, \mathbf{B}_{\mathbf{d}}, \mathbf{K}_{\mathbf{d}}, \mathbf{P}$ у статті не приводяться, так як мають велику розмірність. Моделювання перехідних процесів у ACK із ЛКЦР проводилося у середовищі Simulink MatLAB, структурна схема для моделювання зображена рис 2. Перехідні процеси у АСК із ЛКЦР представлено на рис. 3. Інерційність перехідних процесів у АСК із ЛКЦР мала, що пояснюється малою продуктивністю кондиціонера CV-P 2L N-63B/F-N (продуктивність 5000 м³/год, габарити стельового кондиціонера $3817 \times 395 \times 1010$ мм) та регулюванням параметрів повітряної суміші на виході кондиціонера. Для прецизійних систем кондиціювання необхідно враховувати динамічні властивості приміщення у комплексній моделі (1), при цьому процедура синтезу ЛКЦР не зміниться.

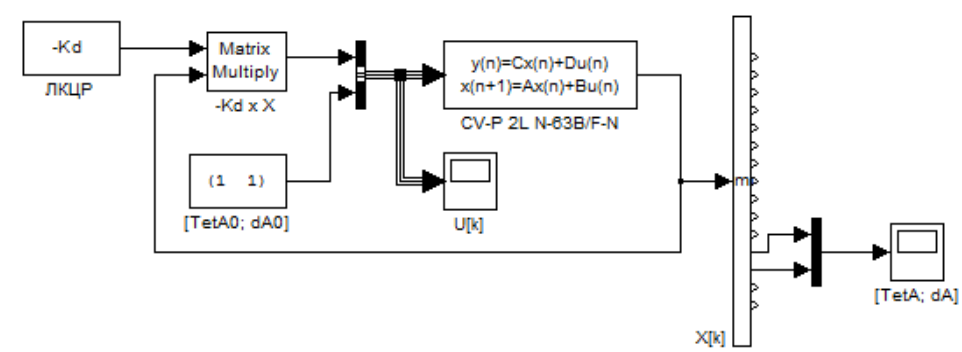

Рис. 2 - Структурна схема АСК із ЛКЦР для моделювання у середовищі Simulink 


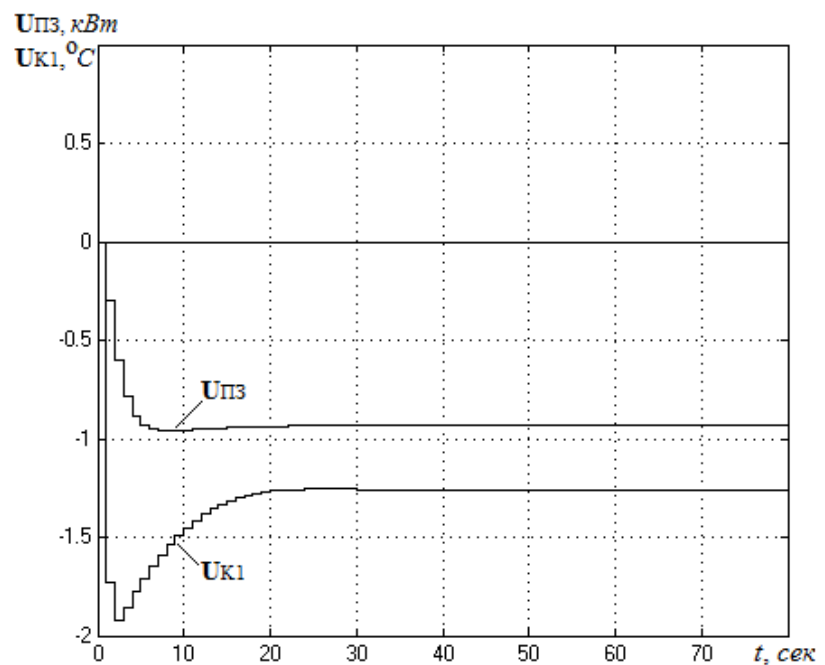

a)

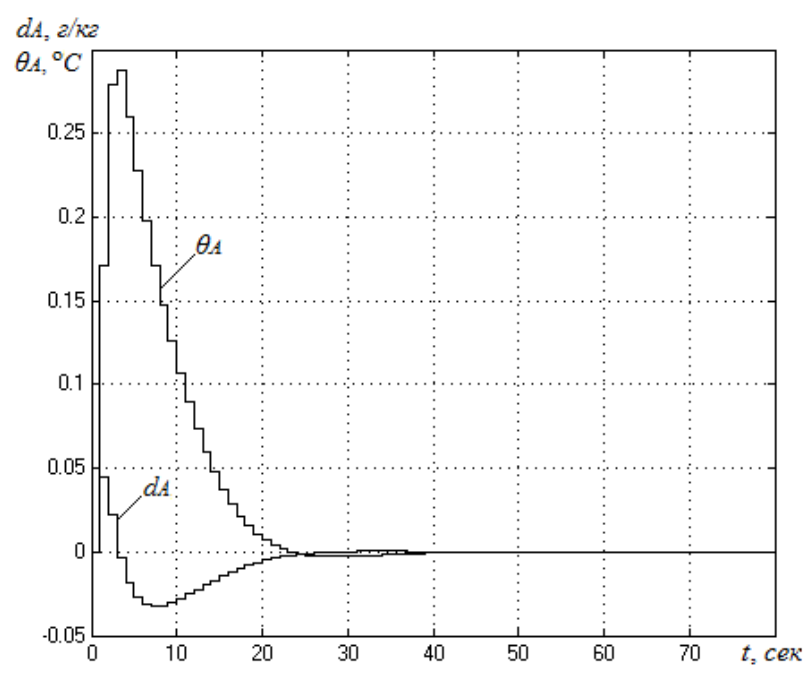

б)

Рис. 3 - Перехідні процеси у АСК із ЛКЦР при одночасному збурені за температурою $\theta_{A 0}=1(t)$ та вологовмістом $d_{A 0}=1(t)$ повітря на вході ПКШМ: $\left.a\right)$ - керуючий вплив ЛКЦР; $\sigma$ ) - перехідні процеси на виході ПКШМ

\section{Висновки}

На конкретному прикладі розглянуто основні принципи синтезу сучасної АСК промислового кондиціонера, які відрізняються від традиційних за такими ознаками. По-перше, це аналіз динаміки тепло- та масообміну обладнання кондиціонера із створенням комплексних моделей ПКШМ як єдиного багатовимірного ОК в координатах температури та вологовмісту повітря. По-друге, розмежування взаємного впливу контурів регулювання температури та вологості за рахунок використання температури та вологовмісту у якості параметрів регулювання. По-третє, використання сучасних процедур синтезу оптимальних багатовимірних регуляторів.

Запропоновано процедуру синтезу багатовимірного ЛКЦР для промислового кондиціонера. Від класичної процедури синтезу ЛКЦР розглянута відрізняється наявністю логічного вибору обладнання для здійснення оптимального керування та використання інтегральної складової у формуванні закону керування.

У подальшому планується провести синтез АСК за методом “оптимального режиму” для промислового кондиціонера із форсуочним зволожувачем та обвідним каналом на зволожувачі. Отримані результати планується порівняти із роботою АСК за методом “точки роси” для промислового кондиціонера із форсуочним зволожувачем.

\section{Література}

[1] Белова Е.М. Центральные системы кондиционирования воздуха в зданиях / Е.М. Белова. -М.: Евроклимат, 2006. -640c.;

[2] Бондарь Е.С. Автоматизация систем вентиляции и кондиционирования воздуха / Е.С. Бондарь, А.С. Гордиенко, В.А. Михайлов, Г.В. Нимич. -К.: ООО “Издательский дом “Аванпост-Прим”, 2005. -560 с.;

[3] Халимовский А.М. Микропроцессорная система автоматического управления параметрами воздуха рабочей среды человека / А.М. Халимовский, О.И. Киселичник, Н.Я. Островерхов и др. // Электроника и связь. -2001. № 13, -C. 50-54.;

[4] Голінко І.М. Аналіз системи керування для штучного мікроклімату за методом “точки роси” / І.М. Голінко, В.Г. Трегуб // Східно-Свропейский журнал передових технологій. -2011, № 2/10(50). -С. 53-55.;

[5] Липа, А.И. Кондиционирование воздуха. Основы теории. Современные технологии обработки воздуха / А.И. Липа. -Одесса: ОГАХ, 2010. -607c.;

[6] Голінко І.М. Аналіз та забезпечення ефективного керування системами штучного мікроклімату / I.М. Голінко, С.Г. Степаненко, І.С. Галицька, В.Ю. Степаненко // Гіротехнології, навігація, керування рухом і конструювання авіаційно-космічної техніки: матеріали IX Міжнародної науково-практичної конференції, 17 18 квітня 2013 р., - Київ, 2013. С. 172-175.;

[7] Вычужанин В.В. Математические модели нестационарных режимов воздухообработки в центральной СКВ / В.В. Вычужанин // Вісник Одеського національного морського університету: Зб. наук. праць. -Одеса: ОНМУ. 2007. Вип. 23,-С.172-185.; 
[8] Коханский А.И. Идентификация передаточных функций охладителя наддувочного воздуха / А.И. Коханский, Э.М. Колпакчи // Науч.-тех. сб. Автоматизация судовых технических средств. 2007. Вып. 12, С.68-77.;

[9] Голінко I.М. Динамічна модель тепломасообміну для водяного охолоджувача промислового кондиціонера / І.М. Голінко // Наукові вісті НТУУ “КПІ”. -2014, № 6. -С. 27-34.;

[10] Голінко I.M. Математичне моделювання процесів тепло- та масообміну для камери парового зволоження / I.М. Голінко, І. С.Галицька, В.Ю. Степаненко // Прикарпатський вісник НТШ. Серія Число. -2014, № 1(25). С. 54-62.;

[11] Голінко I.M. Динамічна модель тепломасообмінних процесів у камері форсуночного зволоження / I.M. Голінко, А.І. Кубрак, І.С. Галицька // Інформаційні системи, механіка та керування. 2014. № 11, С. 61-71.;

[12] Голінко I.M. Комплексна динамічна модель промислового кондиціонера із форсуночним зволожувачем у просторі стану / І.М. Голінко, І.С. Галицька // Гіротехнології, навігація, керування рухом і конструювання авіаційно-космічної техніки: збірка доповідей Х Міжнародної науково-практичної конференції, 16 - 17 квітня 2015 р., - Київ, 2015. С. 201-207.;

[13] Каталог. VENTUS - вентиляционные агрегаты и центральные кондиционеры. -M.: VTSGroup, 2003. -156 с.;

[14] Куо Б. Теория и проектирование цифровых систем управления: пер. с англ. -М.:Машиностроение, $1986 .-448$ с.;

[15] Рей У. Методы управления технологическими процессами / У. Рей. -М.: Мир, 1983. -368 с.;

[16] Голінко I.M. Аналіз системи керування для промислового кондиціонера із парозволожувачем / I.M. Голінко, В.Г. Трегуб // Східно-Свропейский журнал передових технологій. -2012, № 6/8(60). -С. 14-18.;

[17] Краснов Ю.С. Системы вентиляции и кондиционирования / Ю.С. Краснов, А.П. Борисоглебская, А.В. Антипов. -М.: ТермоКул, 2004. -373 с.

\section{References}

[1] Belova E.M. Tsentralnyie sistemyi konditsionirovaniya vozduha v zdaniyah / E.M. Belova. -M.: Evroklimat, 2006. 640s.;

[2] Bondar E.S. Avtomatizatsiya sistem ventilyatsii i konditsionirovaniya vozduha / E.S. Bondar, A.S. Gordienko, V.A. Mihaylov, G.V. Nimich. -K.: OOO “Izdatelskiy dom “Avanpost-Prim”, 2005. -560 s.;

[3] Halimovskiy A.M. Mikroprotsessornaya sistema avtomaticheskogo upravleniya parametrami vozduha rabochey sredyi cheloveka / A.M. Halimovskiy, O.I. Kiselichnik, N.Ya. Ostroverhov i dr. // Elektronika i svyaz. -2001. № 13, -S. 50-54.;

[4] Golinko I.M. Analiz sistemi keruvannya dlya shtuchnogo mikroklimatu za metodom "tochki rosi” / I.M. Golinko, V.G. Tregub // Shidno-Evropeyskiy zhurnal peredovih tehnologiy. -2011, № 2/10(50). -S. 53-55.;

[5] Lipa, A.I. Konditsionirovanie vozduha. Osnovyi teorii. Sovremennyie tehnologii obrabotki vozduha / A.I. Lipa. Odessa: OGAH, 2010. -607s.;

[6] Golinko I.M. Analiz ta zabezpechennya efektivnogo keruvannya sistemami shtuchnogo mikroklimatu / I.M. Golin-ko, S.G. Stepanenko, I.E. Galitska, V.Yu. Stepanenko // Girotehnologiyi, navigatsiya, keruvannya ruhom i konstruyuvannya aviatsiyno-kosmichnoyi tehniki: materiali IH Mizhnarodnoyi naukovo-praktichnoyi konferentsiyi, 17 18 kvitnya 2013 r., - Kiyiv, 2013. S. 172-175.;

[7] Vyichuzhanin V.V. Matematicheskie modeli nestatsionarnyih rezhimov vozduhoobrabotki v tsentralnoy SKV / V.V. Vyichuzhanin // Visnik Odeskogo natsionalnogo morskogo universitetu: Zb. nauk. prats. -Odesa: ONMU. 2007. Vip. 23, -S.172-185;

[8] Kohanskiy A.I. Identifikatsiya peredatochnyih funktsiy ohladitelya nadduvochnogo vozduha / A.I. Kohanskiy, E.M. Kolpakchi // Nauch.-teh. sb. Avtomatizatsiya sudovyih tehnicheskih sredstv. 2007. Vyip. 12, S.68-77.;

[9] Golinko I.M. Dinamichna model teplomasoobminu dlya vodyanogo oholodzhuvacha promislovogo konditsionera / I.M. Golinko // Naukovi visti NTUU “KPI”. -2014, № 6. -S. 27-34.;

[10] Golinko I.M. Matematichne modelyuvannya protsesiv teplo- ta masoobminu dlya kameri parovogo zvolozhennya / I.M. Golinko, I. E.Galitska, V.Yu. Stepanenko // Prikarpatskiy visnik NTSh. Seriya Chislo. -2014, № 1(25). S. 5462 .; 
[11] Golinko I.M. Dinamichna model teplomasoobminnih protsesiv u kameri forsunochnogo zvolozhennya / I.M. Golinko, A.I. Kubrak, I.E. Galitska // Informatsiyni sistemi, mehanika ta keruvannya. 2014. № 11, S. 61-71.;

[12] Golinko I.M. Kompleksna dinamichna model promislovogo konditsionera iz forsunochnim zvolozhuvachem $\mathrm{u}$ prostori stanu / I.M. Golinko, I.E. Galitska // Girotehnologiyi, navigatsiya, keruvannya ruhom i konstruyuvannya aviatsiyno;

[13] kosmichnoyi tehniki: zbirka dopovidey H Mizhnarodnoyi naukovo-praktichnoyi konferentsiyi, 16 - 17 kvitnya 2015 r., - Kiyiv, 2015. S. 201-207.;

[14] Katalog. VENTUS - ventilyatsionnyie agregatyi i tsentralnyie konditsioneryi. -M.: VTSGroup, 2003. -156 c.;

[15] Kuo B. Teoriya i proektirovanie tsifrovyih sistem upravleniya: per. s angl. -M.:Mashinostroenie, 1986. -448 s.;

[16] Rey U. Metodyi upravleniya tehnologicheskimi protsessami / U. Rey. -M.: Mir, 1983. -368 s.;

[17] Golinko I.M. Analiz sistemi keruvannya dlya promislovogo konditsionera iz parozvolozhuvachem / I.M. Golinko, V.G. Tregub // Shidno-Evropeyskiy zhurnal peredovih tehnologiy. -2012, № 6/8(60). -S. 14-18.;

[18] Krasnov Yu.S. Sistemyi ventilyatsii i konditsionirovaniya / Yu.S. Krasnov, A.P. Borisoglebskaya, A.V. Anti-pov. M.: TermoKul, 2004. -373 s.

\section{АППРОКСИМАЦИЯ В ЗАДАЧЕ УПРАВЛЕНИЯ ХАРАКТЕРИСТИКОЙ ЦИФРОВОГО ФИЛЬТРА ДЛЯ СПЕЦИАЛИЗИРОВАННОЙ КОМПЬЮТЕРНОЙ СИСТЕМЫ}

Linearization in a digital filter control characteristic problem for a specialized computer system

Ухина А.В. ${ }^{1}$, к.физ-мат.н., доц. Яценко Т.П. ${ }^{2}$, д.т.н., проф. Ситников В.С. ${ }^{3}$ (Ukhina H.V., Yatsenko T.P., Sytnikov V.S.1)

Одесский национальный политехнический университет, г. Одесса

${ }^{1}$ E-mail: anyuta.uhina@inbox.ru

${ }^{2}$ E-mail: kuwtat@ukr.net

${ }^{3}$ E-mail: sitnvs@mail.ru

Copyright (C) 2014 by author and the journal "Automation technological and business - processes". This work is licensed under the Creative Commons Attribution International License (CC BY). http://creativecommons.org/licenses/by/4.0/

(c) (i) $\begin{aligned} & \text { ONAFT } \\ & \text { Open Access }\end{aligned}$

\section{Аннотация}

Определены зависимости, которые можно использовать для получения линейной характеристики управления АЧХ при аппроксимации характеристики. Показана возможность такого управления. 